Summary of Research on Department of

DE92 012539

Energy Grant DE-F602-87ER13775.A000

During the course of Grant ER 13775 we have constructed an infrared stopped-flow spectrophotometer and initiated a study of the mechanisms of reactions that involve a change in the oxidation state of organometallic complexes. In this summary we will highlight our results on reactions: (1) that formally involve exchange of a charged species between two metal carbonyl anions, (2) that involve addition of an electron to, or removal of an electron from organometallic complexes that contain a metal-metal bond, and (3) between coordination complexes and metal carbonyl anions.

\title{
Construction of the Apparatus
}

In order to study rapid electron transfer reactions of the metal carbonyl anions we had to develop an infrared stopped-flow spectrophotometer. 1 This apparatus combined conventional stopped-flow techniques with an infrared optical system comprised of a carbon monoxide laser, an IRTRAN flow-through cell and a mercury-cadium-telluride detector. As far as we have been able to ascertain, this system is unique. Testing of the system has been extensive with point by point spectra to check calibration of wavelengths, dead time measurements for the stopped-flow, determination of concentration limits and their relationship to solvent concussion waves and comparison to known kinetic systems. ${ }^{2}$ Since our examinations center on metal carbonyl anions, we utilized the reaction with methyl iodide (which is used to measure the nucleophilicity) to test the reliability of the system. Our results were in reasonable qualitative and quantitative agreement with previous results. As a sidelight we expanded 
the interpretation of nucleophilicity to include ligand effects, counter cation effects and solvent effects. ${ }^{2}$

\section{Competition between Metal Carbonyl Anions}

Reaction of a metal carbonyl cation with a metal carbonyl anion leads, ultimately, to bimetallic products. 3,4

$$
\begin{aligned}
& M^{+}+M^{\prime}+M_{2}+M_{2}^{\prime}+M M^{\prime} \\
& M, M^{\prime}=\text { metal carbonyl moieties }
\end{aligned}
$$

This reaction occurs by a single electron transfer giving the odd electron species $M^{\cdot}$ and $M^{\prime} \cdot$, is accompanied by $C 0$ scrambling and leads to $M_{2}, M_{2}^{\prime}$ and MM' in roughly statistical amounts. A second reaction involving a twoelectron oxidation change is observed in some cases. 3,4

$$
\mathrm{M}-\mathrm{CO}^{+}+\mathrm{M}^{--} \rightarrow \mathrm{M}^{-}+\mathrm{M}^{1}-\mathrm{CO}^{+}
$$

This two-electron process is observed when $\mathrm{M}^{-}$is more nucleophilic than $\mathrm{M}^{-}$, occurs more rapidly than the single-electron transfer, involves the transfer of one Co (the rest are not scrambled between metal carbonyl moieties or gaseous $C O$ ) and usually forms $M_{2}$ and $M_{2}^{\prime}$ (very little $M M^{\prime}$ ) as the final products. The results are accommodated (formally) by a transfer of a $\mathrm{CO}^{2+}$ between two metal carbonyl anions with the more nucleophilic retaining the $\mathrm{CO}^{2+}$ and becoming the cation. 3,4

Similar reactions apparently occur in a number of cases for $\mathrm{Fe}(\mathrm{CO})_{4}{ }^{2-}$, but interpretation is complicated by the very rapid reaction between $\mathrm{Fe}(\mathrm{CO})_{4}^{2-}$ and $\mathrm{Fe}(\mathrm{CO})_{5} .^{5}$ 


$$
\mathrm{Fe}(\mathrm{CO})_{4}^{2-}+\mathrm{Fe}(\mathrm{CO})_{5} \rightarrow \mathrm{Fe}_{2}(\mathrm{CO})_{8}^{2-}+\mathrm{CO}
$$

Only in the case of reaction with cations is the $\mathrm{CO}^{2+}$ transfer rapid enough to see the $\mathrm{Fe}(\mathrm{CO})_{5}$ product; in other reactions we see only $\mathrm{Fe}_{2}(\mathrm{CO})_{8}{ }^{2-}$.

$$
\begin{aligned}
& \mathrm{Fe}(\mathrm{CO})_{4}^{2-}+\mathrm{Mn}(\mathrm{CO})_{6}^{+}+\mathrm{Fe}(\mathrm{CO})_{5}+\mathrm{Mn}(\mathrm{CO})_{5}^{--} \\
& 2 \mathrm{Fe}(\mathrm{CO})_{4}^{2-}+\mathrm{Ru}_{3}(\mathrm{CO})_{12}+\mathrm{Fe}_{2}(\mathrm{CO})_{8}^{2-}+\mathrm{Ru}_{3}(\mathrm{CO})_{11^{2-}+\mathrm{CO}}
\end{aligned}
$$

$\mathrm{Fe}_{2}(\mathrm{CO})_{8}^{2-}$ and $\mathrm{W}_{2}(\mathrm{CO})_{10}{ }^{2-}$ also undergo oxidation reactions that we are continuing to examine.

It is also possible to establish competition between metal carbonyl anions for other groups. Here I will briefly describe our results for (formally) $\mathrm{CH}_{3}^{+}$transfer (see proposal section for f'urther development of this concept). Reaction of a methyl complex with a metal carbonyl anion leads to methyl transfer when the reactant anion is more nucleophilic than the product anion. 6,7

$$
\mathrm{CH}_{3} \mathrm{Mn}(\mathrm{CO})_{5}+\mathrm{CpFe}(\mathrm{CO})_{2}^{-} \rightarrow \mathrm{CH}_{3} \mathrm{FeCp}(\mathrm{CO})_{2}+\mathrm{Mn}(\mathrm{CO})_{5}^{-}
$$

Formally the Mn has changed from +1 oxidation state to -1 oxidation state and the $\mathrm{Fe}$ from $\mathrm{O}$ to +2 . These reactions may be considered as a competition of two nucleophiles for the $\mathrm{CH}_{3}{ }^{+}$, but further work is necessary to establish a mechanism. 
Reactions Involving Complexes Containing a Metal-Metal Bond.

Dimers. In many cases reaction of a mononuclear metal carbonyl anion with a metal carbonyl dimer results in electron transfer. 1,8

$$
2 \operatorname{Re}(\mathrm{CO})_{5}^{-}+\mathrm{Mn}_{2}(\mathrm{CO})_{10}+\operatorname{Re}_{2}(\mathrm{CO})_{10}+2 \mathrm{Mn}(\mathrm{CO})_{5}^{-}
$$

Whether reaction occurs is controlled by the two-electron reduction potentials. ${ }^{8}$

$$
M_{2}+2 e^{-} \rightarrow 2 M^{-}
$$

".e have used the anion oxidation potentials and the metal-metal bond strengths to evaluate these potentials and shown that the potentials correctly predict the observed reactions. ${ }^{8}$ In the absence of a cyclopentadienyl on the dimer, an inner sphere mechanism initiated by nucleophilic attack of an anion on a metal of the dimer was indicated. 8 When a cyclopentadier 11 was present on the dimer a direct attack of the anion on the metal leading to a ring-slipped complex, followed by extrusion of a new anion provided a better explanation of the mechanism. ${ }^{8}$

The ordering of the two-electron reduction potentials for the dimers should be generally useful for predicting reactivity: $\mathrm{Cp}_{2} \mathrm{Fe}_{2}(\mathrm{CO})_{4}>$ $\mathrm{Re}_{2}(\mathrm{CO})_{10}>\mathrm{Cp}_{2} \mathrm{~W}_{2}(\mathrm{CO})_{6}>\mathrm{Mn}_{2}(\mathrm{CO})_{10}>\mathrm{Cp}_{2} \mathrm{Ma}_{2}(\mathrm{CO})_{6}>\mathrm{Cp}_{2} \mathrm{Cr}_{2}(\mathrm{CO})_{6}>\mathrm{Co}_{2}(\mathrm{CO})_{8}^{8}$ The potentials change by 1.5 volts through this sequence.

Trinuclear complexes. Reaction of mononuclear anions with Group 8 trinuclear clusters may lead to three separate products depending on the conditions: ${ }^{9}$ (1) Formation of the metal carbonyl dimer and the cluster dianion occurs whenever the two-electron reduction potential for the dimer 
is greater than the two-electron reduction potential of the cluster.

Elimination of $\mathrm{Ee}(\mathrm{CO})_{5}$ and formation of the heterotrimetallic cluster, $\mathrm{MFe}_{2}(\mathrm{CO})_{7}{ }^{-}$occurs for $\mathrm{M}=\operatorname{Re}(\mathrm{CO})_{5}, \mathrm{Mn}(\mathrm{CO})_{5}$ and $\mathrm{CpMo}(\mathrm{CO})_{3} \cdot$ (3) The heterometallic cluster, $\mathrm{MRu}_{3}(\mathrm{CO})_{11^{-}}$is formed for $M=\mathrm{CpFe}(\mathrm{CO})_{2}$ and $\operatorname{Re}(\mathrm{CO})_{5}$. Examples of these reactions are shown below.

$$
\begin{aligned}
& 2 \operatorname{Re}(\mathrm{CO})_{5}^{-}+\mathrm{Os}_{3}(\mathrm{CO})_{12}+\mathrm{Re}_{2}(\mathrm{CO})_{10}+\mathrm{Os}_{3}(\mathrm{CO})_{11}{ }^{2-}+\mathrm{CO} \\
& \mathrm{Mn}(\mathrm{CO})_{5}^{-}+\mathrm{Fe}_{3}(\mathrm{CO})_{12}+\mathrm{MnFe}_{2}(\mathrm{CO})_{12}-\mathrm{Fe}(\mathrm{CO})_{5} \\
& \operatorname{Re}(\mathrm{CO})_{5}^{-}+\mathrm{Ru}_{3}(\mathrm{CO})_{12}+\operatorname{ReRu}_{3}(\mathrm{CO})_{16^{-}}+\mathrm{CO}
\end{aligned}
$$

The electron transfer reaction deperids significantly on the two-electron half-reaction potentials and may lead to reaction in either direction. 9

$$
\mathrm{Mn}_{2}(\mathrm{CO})_{10}+\mathrm{Os}_{3}(\mathrm{CO})_{11}{ }^{2-} \stackrel{\mathrm{CO}}{\rightarrow} 2 \mathrm{Mn}(\mathrm{CO})_{5}{ }^{-}+\mathrm{Os}_{3}(\mathrm{CO})_{12}
$$

The observed reactions allowed evaluation of the two-electron half-reaction potentials.

$$
M_{3}(\mathrm{CO}){ }_{12}+2 \mathrm{e}^{-}+\mathrm{M}_{3}(\mathrm{CO}){ }_{11}^{2-}+\mathrm{CO}
$$

The ordering of the half reaction potentials (all are negative) $\mathrm{Os}_{3}(\mathrm{CO})_{12}$ $<\mathrm{Ru}_{3}(\mathrm{CO})_{12}<\mathrm{Fe}_{3}(\mathrm{CO})_{12}$ was shown to be correct by reactions such as ${ }^{10}$

$$
\mathrm{Os}_{3}(\mathrm{CO})_{11}{ }^{2-}+\mathrm{Ru}_{3}(\mathrm{CO})_{12}+\mathrm{Os}_{3}(\mathrm{CO})_{12}+\mathrm{Ru}_{3}(\mathrm{CO})_{11}{ }^{2-}
$$


All reactions with the clusters have shown very small rate dependences on the nature of the oxidant or the reductant, most consistent with an outer sphere process.

Other Results

Nucleophilicity. As a test of our stopped-flow infrared system and as a basis for comparison to other rate data, we determined the rates of reaction of mononuclear anions with methyl iodide to measure nucleophilicity. ${ }^{2}$ Our values for the second order rate constants were in agreement with those previously determined, indicating the validity of the stopped-flow system. In addition we identified a dependence on phosphine ligands for reaction of anions with methyl iodide that showed the acceleralion in rate expected for an increase in electron density was offset by steric interactions in expanding the coordination sphere.

Coordination complexes. Reaction of metal carbonyl anions with Colophen $3^{3+}$ results in Co(o-phen $3^{2+}$ and the metal carbonyl dimer. 11

$$
2 \operatorname{Re}(\mathrm{CO})_{5}^{-}+2 \mathrm{Co}(\text { o-phen })_{3}^{3+}+\operatorname{Re}_{2}(\mathrm{CO})_{10}+2 \mathrm{Co}(\text { o-phen })_{3}^{2+}
$$

The dependence of the rate on the nature of the metal carbonyl anion is quite different than observed for other reactions of the anions with the order $\mathrm{CpMo}(\mathrm{CO})_{3}{ }^{-}>\mathrm{CpFe}(\mathrm{CO})_{2}{ }^{-}>\mathrm{Mn}(\mathrm{CO})_{5}{ }^{-}>\mathrm{Co}(\mathrm{CO})_{4}{ }^{-}>\operatorname{Re}(\mathrm{CO})_{5}{ }^{-}$. It seems likely that this dependence arises from bond adjustments in proceeding to the transition state of an outer sphere electron transfer process. 11 Structural studies are underway to provide further data to address this possibility. 
Reactions of the metal carbonyl anions with $\mathrm{CrCl}_{3} \cdot 3 \mathrm{CH}_{3} \mathrm{CN}$ also result in electron transfer. ${ }^{12}$ In these reactions metal carbonyl chlorides are observed in addition to metal carbonyl dimers and the dependence on anion is that more typically observed $\left(\mathrm{CpFe}(\mathrm{CO})_{2}{ }^{-}>\operatorname{Re}(\mathrm{CO})_{5}{ }^{-}>\mathrm{Mn}(\mathrm{CO})_{5}{ }^{-}>\mathrm{CpMo}_{(\mathrm{CO})_{3}}{ }^{-}\right.$ $\left.>\mathrm{Co}(\mathrm{CO})_{4}^{-}\right)$. For these reactions we suggest an inner sphere process. 12

Electrochemistry. A natural consequence of our examination of electron transfer reactions is information on reduction potentials. ${ }^{2,4,9,10}$ Most electrochemical studies on metal carbonyl species have showr the electrochemical reactions to be irreversible. In addition many reactions that occur involve two-electron processes,

$$
\mathrm{Mn}_{2}(\mathrm{CO})_{10}+2 e^{-}+2 \mathrm{Mn}(\mathrm{CO})_{5}^{-}
$$

and electrochemical studies provide only the one electron potentials

$$
\begin{aligned}
& \mathrm{Mn}_{2}(\mathrm{CO})_{10}+\mathrm{e}^{-}+\mathrm{Mn}_{2}(\mathrm{CO})_{10}= \\
& \cdot \mathrm{Mn}(\mathrm{CO})_{5}+\mathrm{e}^{-}+\mathrm{Mn}(\mathrm{CO})_{5}^{-}
\end{aligned}
$$

We have used the metal-metal bond energies coupled with potentials for reaction 18 to provide a measure of the two-electron half-reaction potentials (reaction 16)..$^{8}$ our confidence in these potentials is enhanced because they correctly predict the observed reactions. By comparison we have also evaluated the two-electron reduction potentials for the trinuclear clusters, $M_{3}(\mathrm{CO}) 12^{\cdot}$ 


\section{Summary}

We have made substantial progress in our examination of the electron transfer mechanisms of organometallic complexes. A major step was the construction of an infrared stopped-flow system powered by a co laser. Using this system we have observed outer-sphere electron transfer, inner sphere electron transfer, inner sphere electron transfer initiated by nucleophilic attack and group transfer reactions. We have made progress a.long each part of grant ER13775.

\section{DISCLAIMER}

This report was prepared as an account of work sponsored by an agency of the United States Government. Neither the United States Government nor any agency thereof, nor any of their employees, makes any warranty, express or implied, or assumes any legal liability or responsibility for the accuracy, completeness, or usefulness of any information, apparatus, product, or process disclosed, or represents that its use would not infringe privately owned rights. Reference herein to any specific commercial product, process, or service by trade name, trademark, manufacturer, or otherwise does not necessarily constitute or imply its endorsement, recommendation, or favoring by the United States Government or any agency thereof. The views and opinions of authors expressed herein do not necessarily state or reflect those of the United States Government or any agency thereof. 


\section{- References}

1. M. S. Corraine and J. D. Atwood, Reaction of $\operatorname{Re}(\mathrm{CO})_{3}^{-}$with Metal Carbonyl Dimers: Electron Transfer Studied by Infrared Stopped-Elow Kinetics, Inorg. Chem., 28, 3781 (1989).

2. C. K. Lai, W. G. Felghery, Y. Zhen, and J. D. Atwood, Nucleophilicities of the Metal Carbonyl Anions: Effect of Ligands, Solvent and Counter Cation, Inorg. Chem., 28, 3929 (1989).

3. Y. Zhen and J. D. Atwood, Reactions Between Metal Carbonyl Anions and Cations: Rapid Two-Electron Transfer Followed by One-Electron Back Transfer, J. Am. Chem. Soc., 111, 1506 (1989).

4. Y. Zhen, W. G. Feighery, C. K. Lai and J. D. Atwood, Steric and Electronic Factors that Control Two-Electron Transfers Between Metal Carbonyl Cations and Anions, J. Am. Chem. Soc., 111, 7832 (1989).

5. Y. Zhen and J. D. Atwood, manuscript in preparation.

6. P. Wang and J. D. Atwood, unpublished observations.

7. Nucleophilicity may or may not be important. The close relationship between nucleophilicity of $\mathrm{M}^{-}$and the oxidation potential of $\mathrm{M}^{-}{ }^{2}$ makes this difficult to distinguish in some cases.

8. M. S. Corraine and J. D. Atwood, Reaction of Metal Carbonyl Anions with Metal Carbony? Dimers; Thermodynamic and Kinetic Factors that Control the Reactions, submitted.

9. M. S. Corraine and J. D. Atwood, Electron Transfer between Mononuclear Metal Carbonyl Anions $\left(\mathrm{M}(\mathrm{CO})_{5}{ }^{-}, \mathrm{M}=\mathrm{Mn}, \mathrm{Re} ; \mathrm{CpFe}(\mathrm{CO})_{2}{ }^{-} ; \mathrm{CpM}(\mathrm{CO})_{3}{ }^{-}, \mathrm{M}=\right.$ $\mathrm{Cr}, \mathrm{Mo})$ and Trinuclear Clusters $\left(\mathrm{M}_{3}(\mathrm{CO})_{12}, \mathrm{M}=\mathrm{Fe}\right.$, Ru, Os $)$ and Between Trinuclear Dianions $\left(\mathrm{M}_{3}(\mathrm{CO}),{ }^{2-}, \mathrm{M}=\mathrm{Fe}, \mathrm{Ru}, \mathrm{OS}\right)$ and Metal Carbonyl Dimers $\left(\mathrm{Mn}_{2}(\mathrm{CO})_{10}\right.$ and $\mathrm{CpM}_{2}(\mathrm{CO})_{6}, \mathrm{M}=\mathrm{Cr}$, Mo, $\left.\mathrm{W}\right)$, submitced.

10. M. S. Corraine and J. D. Atwood, Electron Transfer between Metal Cluster Complexes: Reaction of the Dianions, $M_{3}(C O), 1^{2-}(M=F e, R u$, Os) with the Dodecacarbonyltrimetal Clusters, $M_{3}(C O)_{12}$, in preparation.

11. C. K. Lai, M. S. Corraine, M. R. Churchill and J. D. Al ind, Kinetics of the Reduction of $\mathrm{Co}(\mathrm{O}-\mathrm{phen}) \mathrm{B}_{3}{ }^{+}$and $\mathrm{Fe}(\mathrm{O}-\mathrm{phen}){ }_{3}{ }^{+}$by Metal Carbonyl Anions, $\operatorname{Re}(\mathrm{CO})_{5}{ }^{-}, \mathrm{Mn}(\mathrm{CO})_{5}{ }^{-}, \mathrm{CpM}(\mathrm{CO})_{3},(\mathrm{M}=\mathrm{Cr}, \mathrm{MO}, \mathrm{W})$ and $\mathrm{CpFe}(\mathrm{CO})_{2}$ $\left(\mathrm{Cp}=\eta^{5}-\mathrm{C}_{5} \mathrm{H}_{5}, 0\right.$-phen $=$ orthophenanthroline $)$; Aralysis in Terms of an Outer Sphere Mechanism. Structural Determinations of PPN $M n(C O)_{4} L$ ( $L=$ $\left.\mathrm{CO}, \mathrm{PE} \mathrm{t}_{3}\right)$, in preparation.

12. C. K. Lai and J. D. Atwood, to be published. 

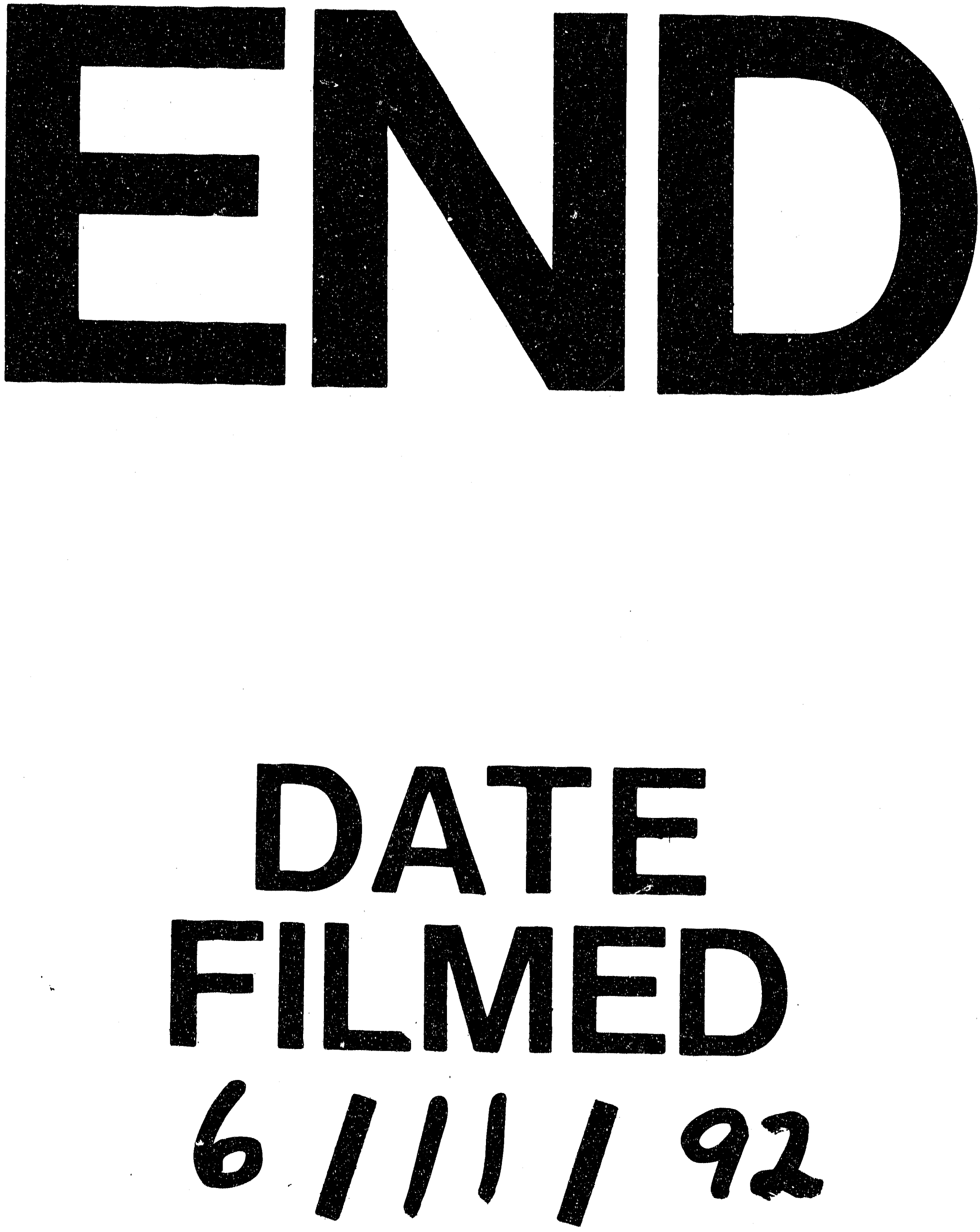
